\title{
IMPLEMENTASI DUAL TONE MULTI FREQUENCY SEBAGAI PENGENDALI LAMPU MENGGUNAKAN TELEPON GENGGAM

\author{
Elfirza Rosiana
}

\author{
Prodi Teknik Elektro FT UNPAM \\ Jln. Puspiptek Raya No 11Buaran, Tangerang Selatan 15310 INDONESIA
}

elfirzarosiana@gmail.com

\begin{abstract}
ABSTRAK
Telepon genggam yang kita miliki, selain dapat digunakan sebagai alat komunikasi juga dapat digunakan untuk mengendalikan peralatan-peralatan elektronik jarak jauh. Oleh karena itu tujuan penelitian ini adalah mengembangkan manfaat telepon genggam sebagai pengendali jarak jauh. Metode penelitian ini memanfaatkan komunikasi DTMF (Dual Tone Multi Frequency). Saat terjadi penekanan pada salah satu tombol yang ada di telepon genggam, maka akan dihasilkan tone yang akan dikirimkan ke telepon genggam penerima. Tone ini kemudian diterjemahkan oleh IC DTMF dekoder (CM8870PI) sehingga menjadi data biner sebagai ouputnya. Output dari rangkaian ini dihubungkan ke IC Demultiplekser (IC SN74154), sehingga setiap data biner yang dihasilkan oleh rangkaian ini akan diterima oleh demultiplekser untuk kemudian di inverting dan di inputkan ke flip-flop SR serta driver relay untuk mengendalikan beban/lampu. sistem ini menghasilkan suatu nada tone yang sangat spesifik dari dua buah nada dengan frekuensi tertentu. Sehingga tidak akan terpengaruh noise dan interferensi nada yang lain.Dua nada tone dihasilkan dari dial telepon genggam, dimana dial angka ganjil dan bintang berfungsi untuk menghidupkan lampu, dial angka genap dan pagar untuk mematikan lampu.

Kata kunci : Telepon Genggam, DTMF, Demultiplekser, Inverter, Flip-flop SR.
\end{abstract}

\begin{abstract}
Mobile phones that we have, in addition can be used as a communication tool can also be used to control the electronic equipment remotely. Therefore the purpose of this study is to develop the benefits of mobile phones as remote control. This research method utilizes DTMF communication (Dual Tone Multi Frequency). When there is an emphasis on one of the buttons on the mobile phone, it will generate a tone that will be sent to the receiver's mobile phone. This tone is then decoded by IC DTMF decoder (CM8870PI) so it becomes binary data as its output. The output of this circuit is connected to IC Demultiplexer (IC SN74154), so any binary data generated by this circuit will be accepted by demultiplexer for inverting and then inputted to the SR flip-flop and relay driver to control the load / lamp. this system produces a very specific tone of two tones of a certain frequency. It will not be affected by noise and other tone interference. Two tone tones are generated from mobile phone dial, where the odd number dial and star function to turn on the light, dial even number and fence to turn off the light.

Keywords: Mobile phones, DTMF, Demultiplexser, Inverter, Flip-flop SR.
\end{abstract}

\section{PENDAHULUAN}

ada era globalisasi ini, perkembangan teknologi semakin maju dan berkembang pesat, yang dahulu tidak mungkin terjadi, tetapi sekarang mungkin saja dapat terjadi. Hal ini menuntut manusia merubah pola hidupnya lebih modern, praktis dan efisien.

Seiring kemajuan teknologi, tingkat mobilitas dan cara berpikir manusia pun kini semakin meningkat pula. Oleh karena itu, manusia dituntut untuk dapat melakukan berbagai 
aktifitas dengan cepat dan dengan durasi waktu yang begitu singkat. Apabila mengamati kehidupan di sekitar, masyarakat masih bergantung pada alat seperti remote control untuk mengendalikan lampu.

Melihat keadaan seperti itu ada beberapa hal yang dapat dilakukan untuk mengatasi permasalahan tersebut dengan membangun sebuah sistem yang dapat dimanfaatkan untuk kendali jarak jauh yang mampu mengontrol alat otomatisasi pada lampu.

Saat ini dunia telekomunikasi, khususnya ponsel sangat berkembang dengan cepat. Namun, perkembangan teknologi ponsel hanya bersifat individual dan tidak nyata atau maya.

Adanya konsep seperti ini, dirancang sebuah sistem komunikasi antar ponsel dimana nantinya komunikasi antar ponsel tersebut dapat memberikan layanan secara nyata dan dapat dirasakan langsung manfaatnya seperti pengontrolan lampu, sistem akan bekerja dengan sendirinya.

Sistem ini dibuat untuk mengendalikan lampu dengan memanfaatkan Dual Tone Multi frequency melalui telepon genggam.

\section{DASAR TEORI}

\section{A. Telepon Seluler (Telepon Genggam)}

Telepon Seluler atau telepon genggam
atau handphone adalah perangkat telekomunikasi elektronik yang mempunyai kemampuan dasar yang sama dengan telepon konvensional saluran tetap, namun dapat dibawa kemana-mana (portable, mobile) dan tidak perlu disambungkan dengan jaringan telepon menggunakan kabel. Saat ini Indonesia mempunyai dua jaringan telepon nirkabel yaitu sistem GSM (Global System for Mobile Telecomunications) dan sistem CDMA (Code Division Multiple Access). Badan yang mengatur telekomunikasi seluler Indonesia adalah Asosasi Telekomunikasi Indonesia (ATSI).

\section{B. Cara Kerja Telepon Seluler}

Didalam ponsel, terdapat sebuah pengeras suara, mikrofon, papan tombol, tampilan layar, dan powerful circuit board dengan mikroprosesor yang membuat setiap telepon seperti komputer mini. Ketika berhubungan dengan jaringan nirkabel, sekumpulan teknologi tersebut memungkinkan penggunanya untuk melakukan panggilan atau bertukar data dengan telepon lain atau dengan komputer.
Jaringan nirkabel beroperasi dalam sebuah jaringan yang membagi kota atau wilayah kedalam sel-sel yang lebih kecil. Satu sel mencakup beberapa blok kota atau sampai 250 mil persegi. Setiap sel menggunakan sekumpulan frekuensi radio atau saluran-saluran untuk memberikan layanan di area spesifik. Kekuatan radio ini harus dikontrol untuk membatasi jangkauan sinyal geografis. Oleh Karena itu, frekuensi yang sama dapat digunakan kembali di sel terdekat. Maka banyak orang dapat melakukan percakapan secara simultan dalam sel yang berbeda di seluruh kota atau wilayah, meskipun mereka berada dalam satu saluran.

\section{Dual Tone Multi Frequency (DTMF)}

Dewasa ini hampir semua ponsel yang ada sudah menggunakan tombol tekan yang disebut ponsel Dual Tone Multi Frequency (DTMF). Seperti halnya saat kita berkomunikasi, pengendali ini dapat digunakan pada jarak yang relatif luas.

Mekanisme rangkaian ini menggunakan IC CM8870PI sebagai penerjemah sinyal input DTMF. Pada ponsel jenis ini setiap tombol membangkitkan nada sebagai pengganti pulsa dial.

Nada ini dihasilkan dari kombinasi dua frekuensi yang berbeda. Kedelapan frekuensi ini dibagi dalam dua kelompok, yaitu kelompok frekuensi rendah dan kelompok frekuensi tinggi.

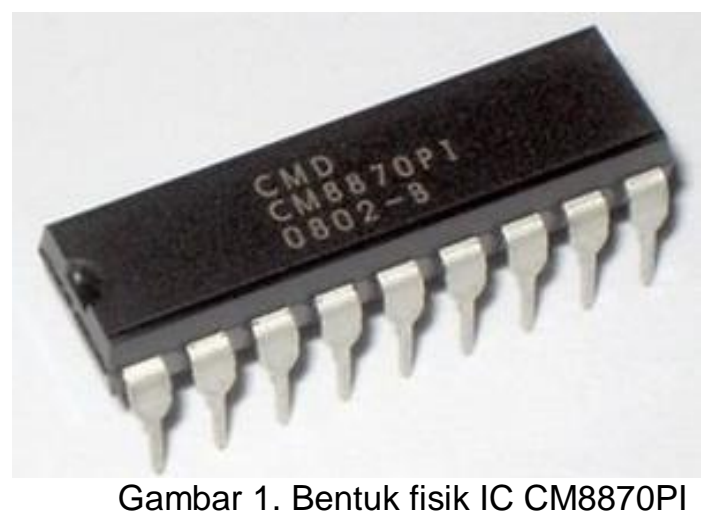

IC CM8870PI merupakan IC penerima DTMF yang didalamnya terdapat dua fungsi sekaligus, yaitu sebagai filter band pass dan penerjemah data digital (digital decoder).

Pada bagian filternya menggunakan teknik switchdari kapasitor untuk kelompok filter high pass dan filter low pass. Pada bagian decodemya menggunakan teknik penghitungan digital untuk mendeteksi dan menerjemahkan 16 pasangan nada DTMF menjadi 4-bit kode.

IC CM8870PI ditunjukkan pada gambar 2 berikut ini: 


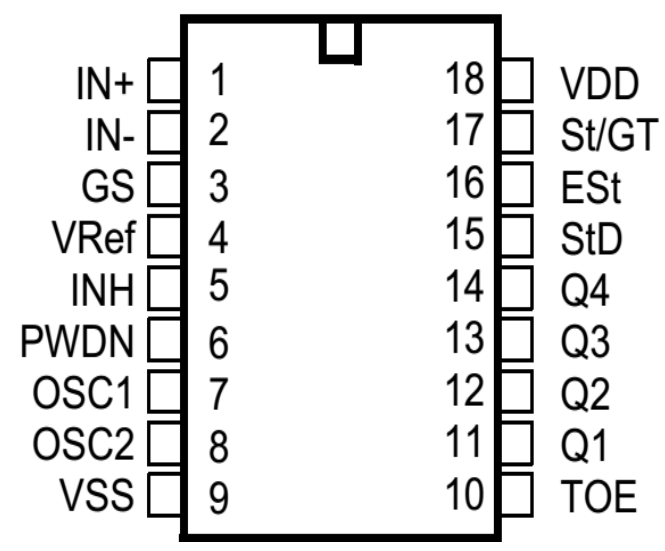

Gambar 2.Datasheet IC CM8870PI

IC CM8870PI ini akan menerjemahkan sinyal yang ada diberikan pada inputnya, yang merupakan sinyal DTMF, menjadi 4 bit data digital pada outputnya. IC CM8870PI akan mengkodekan sinyal DTMF yang masuk dan menghasilkan pulsa-pulsa keluaran melalui pin $11,12,13,14$ dan 15 akan berlogika 1 setiap ada sinyal DTMF (bila keypad ditekan), namun akan kembali berlogika 0 bila keypad tidak ditekan. Sebaliknya bila output dari pin 11, 12, 13 dan 14 (Q1, Q2, Q3 dan Q4) akan terkunci pada masukan sinyal DTMF terakhir.

\section{Demultiplekser 4 ke 16 Jalur}

Demultiplekser adalah suatu rangkaian yang mendistribusikan satu masukan ke lebih dari satu keluaran. Demultiplekser disebut juga data distributor dan dapat digunakan sebagai dekoder.

Pemilihan saluran keluaran dilakukan oleh sinyal kontrol. Sinyal kontrol merupakan masukan yang berfungsi untuk mengarahkan setiap sinyal masukan pada saluran keluaran yang dipilih. Suatu demultiplekser dengan $n$ sinyal kontrol akan memiliki $2^{\mathrm{n}}$ saluran keluaran.

Demultiplekser akan menerima masukan dan meneruskannya ke salah satu dari beberapa keluaran yang mungkin.Demultiplekser memiliki satu kanal input yang didistribusikan ke beberapa kanal output. Selektor input menentukan ke output mana input data akan didistribusikan. Jumlah selektor dilihat dari banyaknya kanal output.

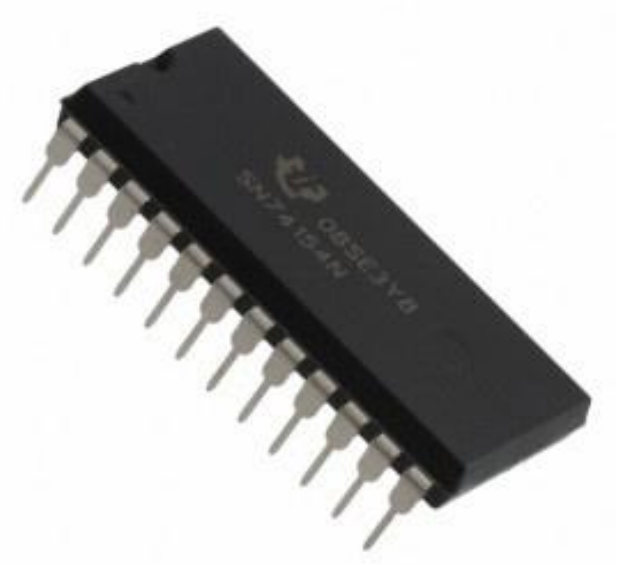

Gambar 3. Bentuk fisik IC SN74154N

IC SN74154 merupakan demultiplekser yang digunakan untuk menyalurkan satu data ke 16 jalur keluaran. Komponen ini mempunyai 4 masukan data yang bisa dipilih salah satu. Untuk memilih keluaran mana yang akan mengeluarkan data, diperlukan 4 buah masukan pemilih, yaitu $A, B, C$ dan $D$.

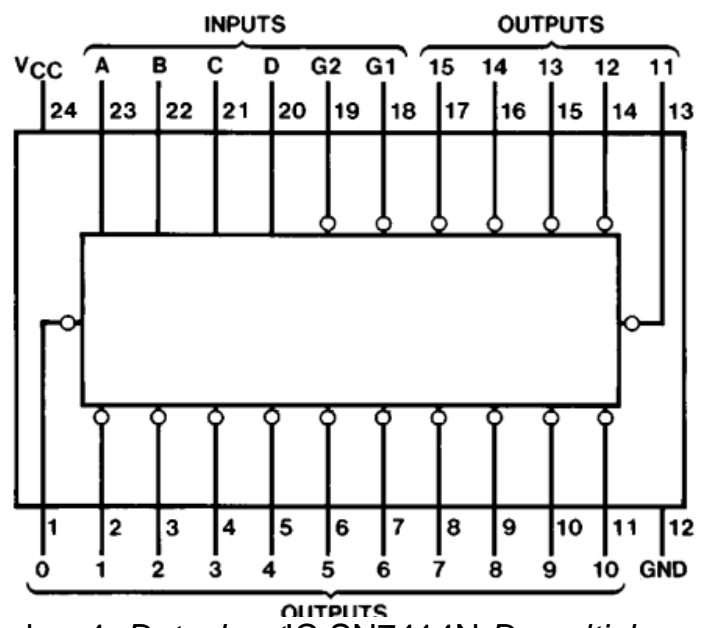

Gambar 4. DatasheetlC SN7414N Demultiplexer 4 ke16 jalur

\section{S-R Flip Flop}

S-R Flip-flop merupakan FF yang tersederhana dan rangkaian dasar yang digunakan untuk membangun semua jenis FF yang akan dibahas nanti. Simbol umum dan tabel operasinya adalah : 


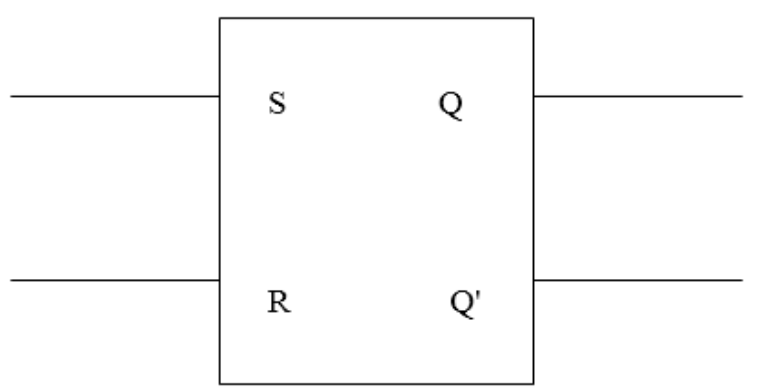

Gambar 5. Simbol umum S-R Flip-Flop

Tabel 1. Tabel Operasi S-R FF:

\begin{tabular}{|l|l|l|l|l}
\hline $\mathrm{S}$ & $\mathrm{R}$ & $\mathrm{Q}$ & $\overline{\mathrm{Q}}$ & \\
\hline 0 & 0 & $\mathrm{Q}$ & $\mathrm{Q}^{\prime}$ & Fungsi memory \\
0 & 1 & 0 & 1 & fungsi reset \\
1 & 0 & 1 & 0 & fungsi set \\
1 & 1 & - & - & tidak didefinisikan \\
\hline
\end{tabular}

Tabel operasi diatas menerangkan hal-hal sebagai berikut :

1. Jika $S=R=0$, maka kedua outputnya $Q$ dan Q' akan tetap bernilai sama seperti sebelumnya. Oleh karena itu, operasi ini disebut memory, karena FF nilainya akan selalu sama dengan keadaan sebelumnya selama tidak direset.

2. Jika $S=0$ dan $R=1$, maka $Q$ akan berlogika 0 dan Q' berlogika 1.Oleh karena itu,operasi ini disebut Reset, karena outputnya direset ke logika 0 kembali.

3. Jika $S=1$ dan $R=0$, maka $Q$ akan berlogika 1 dan Q' berlogika 0. Oleh karena itu operasi ini disebut set, karena outputnya diSet ke logika 1.

4. Jika $S=R=1$, maka hasilnya tidak didefinisikan, karena kombinasi ini akan membuat $Q=Q$ ' $=0$. Kondisi ini tidak benar, karena Q' merupakan komplemen dari Q.

Tergantung dari pintu yang digunakan dalam disain rangkaian digitalnya, fungsi memory dan tidak didefinisikan serta fungsi set dan reset FF ini dapat saling bergantian.

\section{E. Driver Relay}

IC ULN2003 adalah sebuah IC dengan ciri memiliki 7-bit input, tegangan maksimum 50 volt dan arus $500 \mathrm{~mA}$. IC ini termasuk jenis TTL. Di dalam IC ini terdapat transistor darlington. Transistor darlington merupakan 2 buah transistor yang dirangkai dengan konfigurasi khusus untuk mendapatkan penguatan ganda sehingga dapat menghasilkan penguatan arus yang besar.

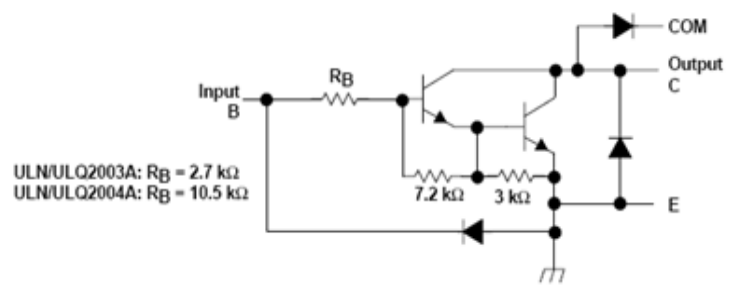

Gambar 6. Rangkaian Darlington IC ULN 2003

IC ULN 2003 merupakan IC yang mempunyai 16 buah pin, pin ini berfungsi sebagai input, output dan pin untuk catu daya. Catu daya ini terdiri dari catu daya (+) dan ground. IC ULN 2003 biasa digunakan sebagai driver motor stepper maupun driver relay.

Bentuk fisik dari IC ULN 2003 adalah sebagai berikut:

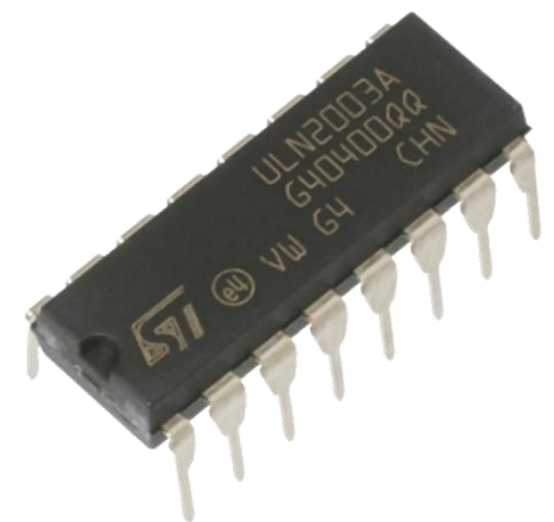

Gambar 7. Bentuk Fisik IC ULN2003

Sedangkan isi dari IC ULN 2003 dan fungsi dari masing-masing pin adalah sebagai berikut:

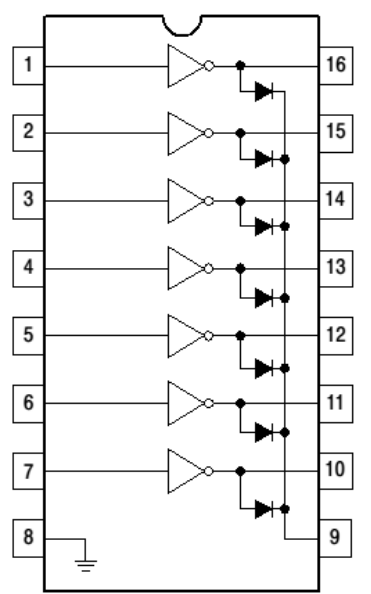

Gambar 8. Transistor Darlington Dalam IC ULN 2003

\section{METODOLOGI}

\section{A.Blok Diagram Sistem Kendali}

Secara umum rangkaian sistem kontrol jarak jauh dengan menggunakan sistem pemanggilanhandphone, memiliki beberapa blok 
rangkaian, yaitu rangkaian power supply, DTMF decoder, demultiplekser, dekoder BCD ke 7 segment, S-R flip-flop, driver relay dan lampu.

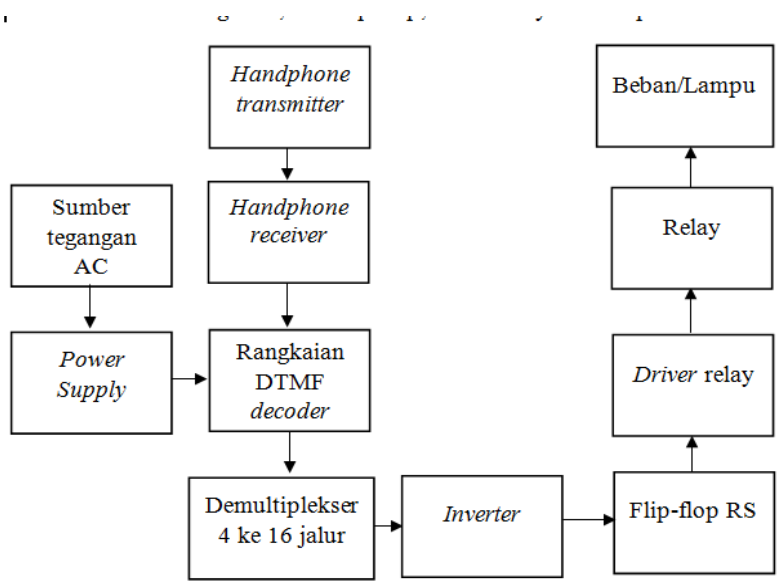

Gambar 9. Diagram Blok sistem kendali

\section{B. Perancangan Rangkaian DTMF Dekoder}

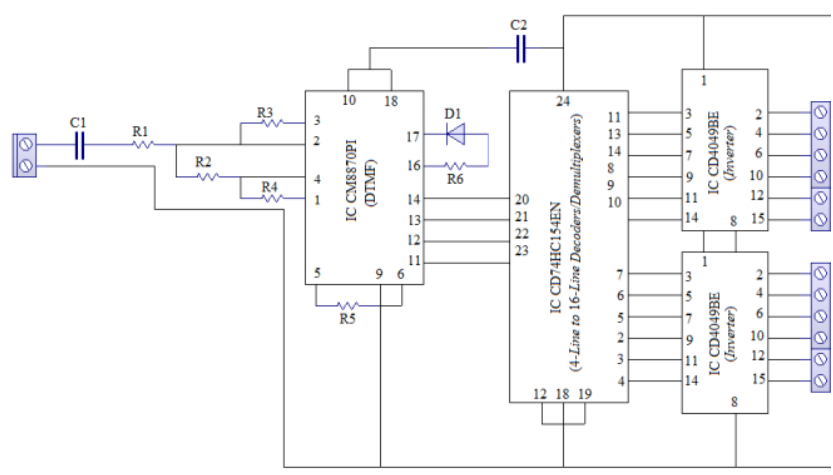

Gambar 10. Skematik Rangkaian DTMF, Demultiplekser dan Inverter

Rangkaian ini merupakan sistem pengendali lampu yang terdiri dari beberapa bagian utama yaitu ponsel (sebagai media pengendali), Power Supply (sebagai sumber tegangan), IC CM8870PI (sebagai dekoder atau penerjemah sinyal DTMF), IC SN74LS47N (BCD to Seven Segment Decoders), IC CD74HC154EN (sebagai demultiplekser 4 ke 16 jalur), IC CD4049BE (sebagai Inverter), IC CD4013BE dan IC CD4043BE (sebagai driver rangkaian) dan sistem relay (sebagai pengaktifan kerja rangkaian). Seluruh proses kendali dalam sistem ini terpusat pada dekoder.

Petunjuk pengoperasian sistem kendali dengan menggunakan ponsel sebagai berikut:

1. Pemakai menggunakan ponsel pribadi untuk memanggil ponsel yang telah dihubungkan pada rangkaian.
2. Untuk mengaktifkan sistem kendali, pemakai harus menekan keypad pada ponsel sehingga bisa mengaktifkan relay.

3. Tombol-tombol DTMF yang ditekan akan menghasilkan sinyal pada frekuensi tertentu (penjumlahan frekuensi atas dengan frekuensi bawah)

4. Keluaran dekoder akan dilanjutkan sistem driver dan relay untuk mengendalikan objek yaitu lampu.

\section{B. Perancangan Rangkaian S-R Flip- flop dan Relay}

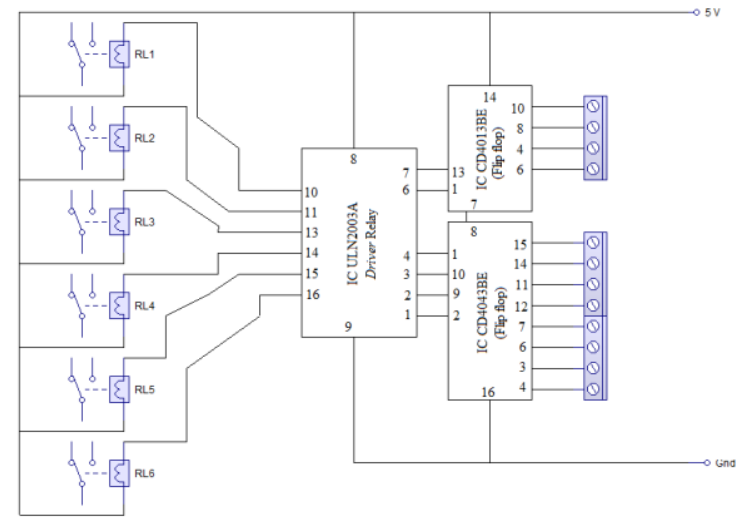

Gambar 11. Skematik Rangkaian S-R Flip-flop dan Relay

Rangkaian ini menggunakan 6 buah relay sebagai saklar on off pada lampu, IC ULN2003A sebagai driver relay, IC CD4043BE SR Flip-Flop dan IC CD4013 Data Flip-flop sebagai pengendali relay. Meskipun IC CD4013 merupakan data flip-flop, namun pin yang dipakai hanya set dan resetnya saja, yaitu pin 3 , pin 5, pin 8, dan pin 10.

\section{Perancangan Diagram Alir Rangkaian \\ Secara umum rangkaian pengendali lampu dengan menggunakan sistem pemanggilan ponsel, adalah sebagai berikut:}




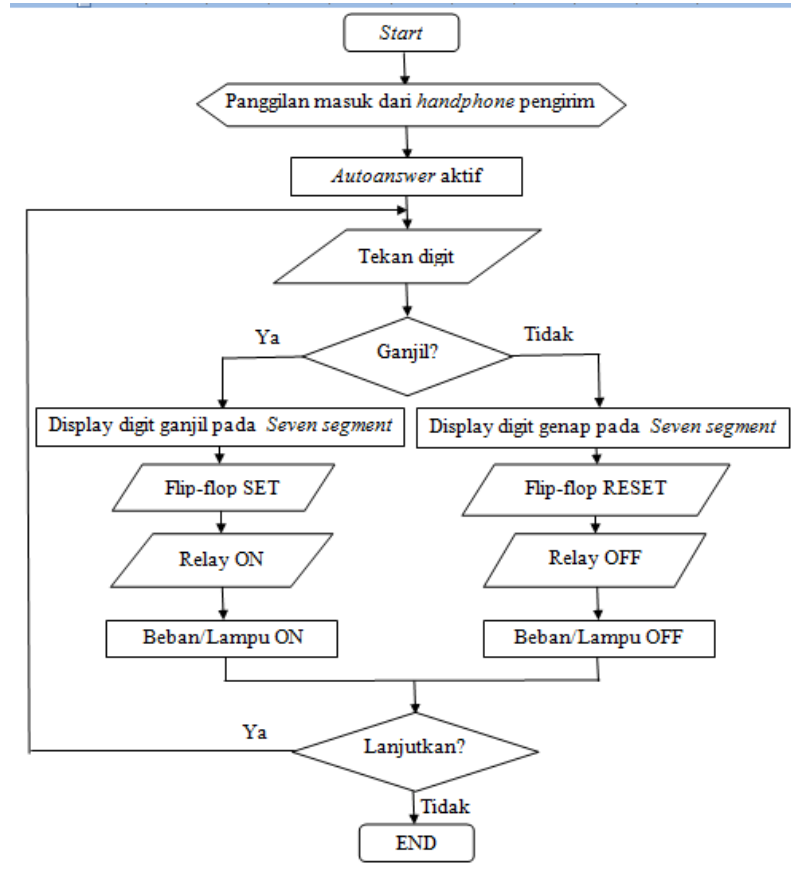

Gambar 12. Diagram Alir Rangkaian Pengendali Lampu Menggunakan Sistem Pemanggilan Ponsel.

Cara kerja rangkaian DTMF ini, dimulai dengan menghubungi ponsel receiver, yaitu ponsel yang terhubung pada input DTMF. Kemudian setelah panggilan terjawab otomatis (auto answer), dial tombol (keypad) pada ponsel transmitter.

Untuk mengetahui apakah DTMF bekerja atau tidak maka kaki 15 (Std) dipasang sebuah LED yang akan aktif high ketika ada input DTMF dan kembali low ketika tidak ada input. Kemudian outputnya dihubungkan dengan IC BCD to Seven Segment Decoders yang menampilkan digit yang ditekan pada handphone. Dimana dial digit ganjil berfungsi untuk menghidupkan lampu, sedangkan dial digit genap berfungsi untuk mematikan lampu.

Tabel 2 Tabel kondisi sistem kendali lampu menggunakan ponsel.

\begin{tabular}{|c|c|c|l|}
\hline No & Dial & Status & \multicolumn{1}{|c|}{ Fungsi } \\
\hline 1 & 1 & 0001 & Saklar ON untuk lampu 1 \\
\hline 2 & 2 & 0010 & Saklar OFF untuk lampu 1 \\
\hline 3 & 3 & 0011 & Saklar ON untuk lampu 2 \\
\hline 4 & 4 & 0100 & Saklar OFF untuk lampu 2 \\
\hline 5 & 5 & 0101 & Saklar ON untuk lampu 3 \\
\hline 6 & 6 & 0110 & Saklar OFF untuk lampu 3 \\
\hline 7 & 7 & 0111 & Saklar ON untuk lampu 4 \\
\hline 8 & 8 & 1000 & Saklar OFF untuk lampu 4 \\
\hline 9 & 9 & 1001 & Saklar ON untuk lampu 5 \\
\hline 10 & 0 & 1010 & Saklar OFF untuk lampu 5 \\
\hline 11 & $*$ & 1011 & Saklar ON untuk lampu 6 \\
\hline 12 & $\#$ & 1100 & Saklar OFF untuk lampu 6 \\
\hline
\end{tabular}

HASIL DAN PEMBAHASAN

\section{A. Hasil Pengukuran Rangkaian Power} Supply

Tabel 3. Hasil pengujian Rangkaian Power Supply

\begin{tabular}{|c|c|c|}
\hline Output & $\begin{array}{c}\text { Output yang diinginkan } \\
(V)\end{array}$ & $\begin{array}{c}\text { Output yang dihasilkan } \\
(\bar{V})\end{array}$ \\
\hline Output V1 & 5 & 4.9 \\
\hline Output V2 & 12 & 11.8 \\
\hline
\end{tabular}

Pengujian pada bagian rangkaian catu daya ini dilakukan dengan mengukur tegangan keluaran dari rangkaian ini dengan menggunakan voltmeter digital. Dari hasil pengujian diperoleh tegangan keluaran rata-rata pertama sebesar 4,9 volt. Sedangkan tegangan keluaran rata-rata kedua adalah sebesar 11,9 volt. Tegangan keluaran pertama digunakan untuk mensuplay tegangan ke rangkaian.

\section{B. Hasil Pengujian Sinyal DTMF}

Gambar 13 menunjukkan gambar sinyal yang dikeluarkan oleh digit 1 DTMF pada osiloskop:

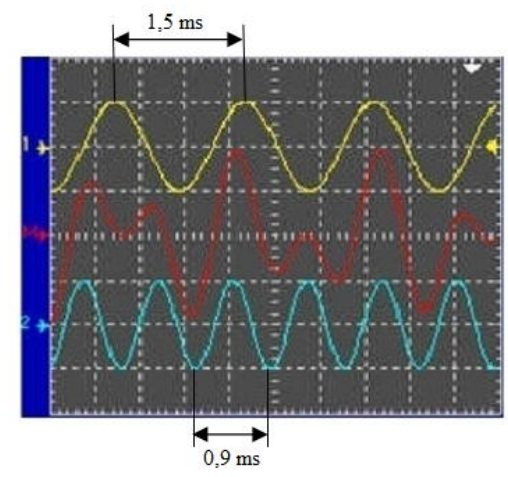

Gambar 13. Sinyal Digit 1 DTMF 
denganF $_{\text {low }}=667 \mathrm{HzF}_{\text {high }}=1111 \mathrm{~Hz}$

Dimana perhitungan periode rendah $\left(\mathrm{T}_{\text {low }}\right)$ dan frekuensi rendah $\left(\mathrm{F}_{\text {low }}\right)$ gelombang pada gambar 13, yaitu:

$$
\begin{aligned}
\mathrm{T}_{\text {low }}= & 1,5 \mathrm{~ms} \\
= & 15 \times 10^{-4} \mathrm{~s} \\
\mathrm{~F}_{\text {low }}= & \frac{1}{\mathrm{~T}}=\frac{1}{15} \times \frac{1}{10^{-4}} \\
= & 0,0667 \times 10^{4} \mathrm{~Hz} \\
= & 667 \mathrm{~Hz}
\end{aligned}
$$

Sedangkan untuk periode tinggi $\left(\mathrm{T}_{\text {high }}\right)$ dan frekuensi tinggi $\left(\mathrm{F}_{\text {high }}\right)$ gelombang yaitu:

$$
\begin{aligned}
& \mathrm{T}_{\text {high }}=0,9 \mathrm{~ms} \\
& =9 \times 10^{-4} \mathrm{~s} \\
& \mathrm{~F}_{\text {high }}=\frac{1}{\mathrm{~T}}=\frac{1}{9} \times \frac{1}{10^{-4}} \\
& =0,1111 \times 10^{4} \mathrm{~Hz} \\
& =1111 \mathrm{~Hz}
\end{aligned}
$$

Digit 2 DTMF ditunjukkan oleh gambar 14, dibawah ini:

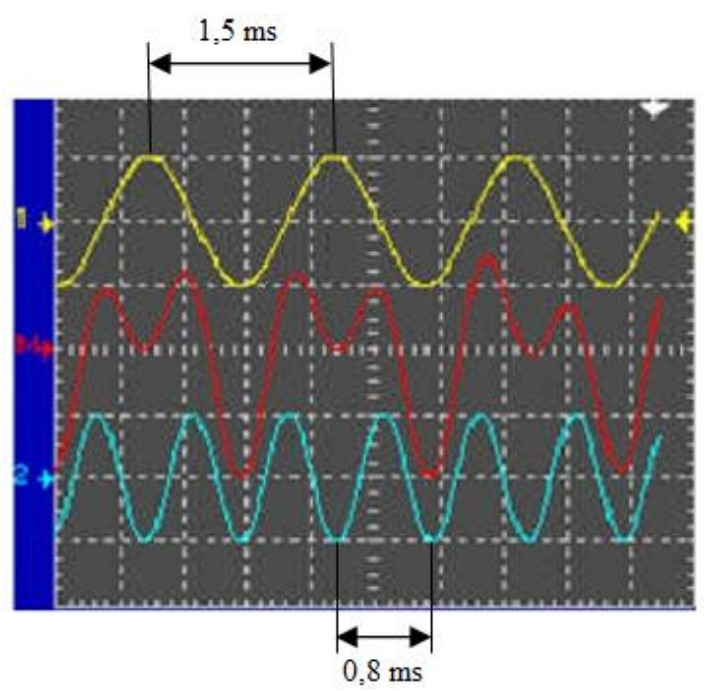

Gambar 14. Sinyal Digit 2 DTMF

dengan $\mathrm{F}_{\text {low }}=667 \mathrm{HzF}_{\text {high }}=1250 \mathrm{~Hz}$

Perhitungan periode rendah $\left(\mathrm{T}_{\text {low }}\right)$ dan frekuensi rendah $\left(\mathrm{F}_{\text {low }}\right)$ gelombang pada gambar 4.2 yaitu:

$$
\begin{aligned}
\mathrm{T}_{\text {low }}= & 1,5 \mathrm{~ms} \\
& =15 \times 10^{-4} \mathrm{~s} \\
\mathrm{~F}_{\text {low }}= & \frac{1}{\mathrm{~T}}=\frac{1}{15} \times \frac{1}{10^{-4}}
\end{aligned}
$$

$$
\begin{aligned}
& =0,0667 \times 10^{4} \mathrm{~Hz} \\
& =667 \mathrm{~Hz}
\end{aligned}
$$

Sedangkan untuk periode tinggi $\left(\mathrm{T}_{\text {high }}\right)$ dan frekuensi tinggi $\left(\mathrm{F}_{\text {high }}\right)$ gelombang yaitu:

$$
\begin{aligned}
\mathrm{T}_{\text {high }}=0,8 \mathrm{~ms} & \\
& =8 \times 10^{-4} \mathrm{~s} \\
\mathrm{~F}_{\text {high }} & =\frac{1}{\mathrm{~T}}=\frac{1}{8} \times \frac{1}{10^{-4}} \\
& =0,125 \times 10^{4} \mathrm{~Hz} \\
& =1250 \mathrm{~Hz}
\end{aligned}
$$

Dari hasil pengujian diperoleh gambar sinyal yang dikeluarkan oleh digit DTMF (Dual Tone Multiple Frequency) pada osiloskop dimana sinyal yang berwarna kuning merupakan bentuk gelombang dari frekuensi rendah dan bentuk gelombang yang berwarna biru menunjukkan frekuensi tinggi.

Setelah perhitungan gelombang didapatkan frekuensi rendah dan frekuensi tinggi pada tone handphone, dimana hasil perhitungan sudah mendekati nilai frekuensi pada datasheet IC CM8870.

\section{Hasil pengujian Rangkaian Dekoder DTMF}

Dari hasil pengujian dapat dilihat pada tabel 4 ketika angka satu 1 pada handphone pengirim di tekan maka dari sisi handphone penerima memberikan sinyal ke input IC DTMF, kemudian pada IC DTMF terjadi konversi dari pasangan frekuensi $697 \mathrm{~Hz}$ dan $1209 \mathrm{~Hz}$ menjadi kode biner 0001 dimana dalam kode biner ini dari hasil pengujian bisa dibuktikan dengan nyalanya led dan rangkaian seven segment menampilkan angka 1, dimana kode biner ini digunakan sebagai input pada IC SN74LS47N, yang nantinya akan digunakan untuk pemicu kerjanya IC Flip Flop Set/Reset untuk menggerakan relay.

Tombol angka satu ini digunakan untuk menyalakan lampu 1. Sedangkan untuk mematikan lampu 1, handphone pengirim cukup menekan tombol angka 2, dimana angka 2 ini termasuk gabungan frekuensi $697 \mathrm{~Hz}$ dan 1336 $\mathrm{Hz}$, kemudian setelah sinyal ini terdeteksi oleh IC DTMF maka frekuensi $697 \mathrm{~Hz}$ dan $1336 \mathrm{~Hz}$ akan dirubah ke bentuk kode biner yaitu menjadi biner 0010 dan dari hasil pengujian dibuktikan dengan nyalanya led dan rangkaian seven segment menampilkan angka 2, dengan demikian maka rangkaian ini telah berfungsi dengan baik. 
Tabel 4. Tabel Tegangan Kerja IC CM8870PI (DTMF)

\begin{tabular}{|c|c|c|c|c|c|c|}
\hline \multirow[t]{2}{*}{ keypad } & $\begin{array}{c}\text { Low } \\
\text { DTMF }\end{array}$ & $\begin{array}{c}\text { High } \\
\text { DTMF }\end{array}$ & \multicolumn{4}{|c|}{ Output (volt) } \\
\hline & $\begin{array}{c}\text { Frequency } \\
(\mathrm{Hz})\end{array}$ & $\begin{array}{c}\text { Frequency } \\
(\mathrm{Hz})\end{array}$ & Q4 & Q3 & Q2 & Q1 \\
\hline 1 & 667 & 1111 & 0 & 0 & 0 & 4,22 \\
\hline 2 & 667 & 1250 & 0 & 0 & 4,22 & 0 \\
\hline 3 & 667 & 1428 & 0 & 0 & 4,22 & 4,21 \\
\hline 4 & 769 & 1111 & 0 & 4,22 & 0 & 0 \\
\hline 5 & 769 & 1250 & 0 & 4,18 & 0 & 4,20 \\
\hline 6 & 769 & 1428 & 0 & 4,22 & 4,39 & 0 \\
\hline 7 & 833 & 1111 & 0 & 4,20 & 4,19 & 4,18 \\
\hline 8 & 833 & 1250 & 4,22 & 0 & 0 & 0 \\
\hline 9 & 833 & 1428 & 4,22 & 0 & 0 & 4,21 \\
\hline 0 & 909 & 1250 & 4,18 & 0 & 4,20 & 0 \\
\hline$*$ & 909 & 1111 & 4,21 & 0 & 4,21 & 4,22 \\
\hline$\#$ & 909 & 1428 & 4,22 & 4,22 & 0 & 0 \\
\hline
\end{tabular}

\section{Pengujian Sistem Kerja Rangkaian.}

\section{Sistem pemanggilan ponsel}

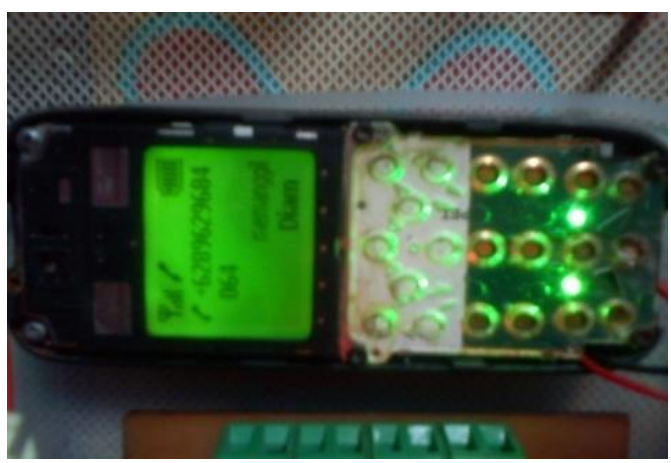

Gambar 15. Panggilan masuk dari handphone pengirim

2. Auto answer mode pada handphone penerima

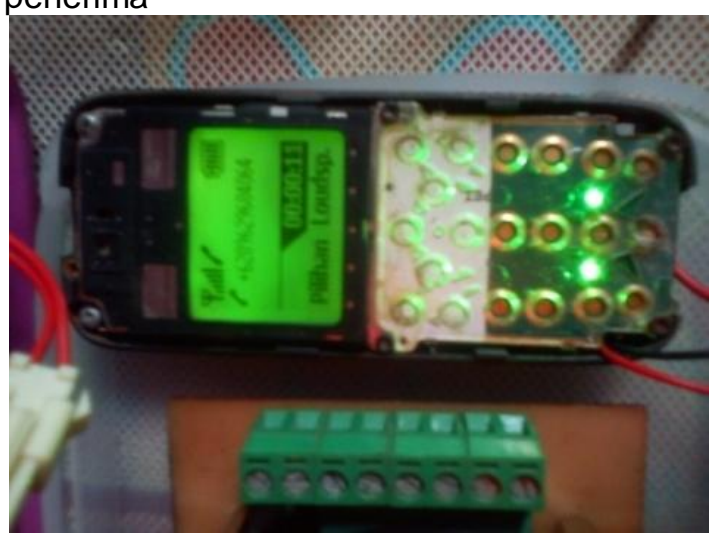

Gambar 16. Tampilan auto answer (jawab otomatis)

3. Dial 1 beban 1 hidup dan seven segment menampilkan digit 1

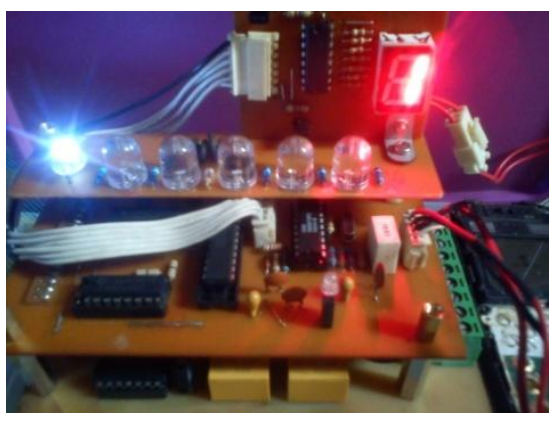

Gambar 17. Display digit 1 beban 1 hidup

Secara keseluruhan sistem kerja rangkaian telah berfungsi dengan baik sesuai flowchart. Dimana dial angka ganjil dan bintang berfungsi untuk menghidupkan lampu, dial angka genap dan pagar untuk mematikan lampu. Saat dial angka 1, 3, 5, 7, 9 dan * maka lampu akan menyala. Sedangkan dial angka 2, 4, 6, 8, 0 dan \# maka lampu akan mati.

\section{KESIMPULAN}

Berdasarkan hasil dari perancangan, pembuatan, dan implementasi alat, maka didapatkan kesimpulan secara menyeluruh mengenai pembuatan alat pengendali lampu menggunakan telepon genggam diantaranya sebagai berikut:

1. Alat ini dapat berfungsi dengan baik untuk menghidupkan dan mematikan lampu melalui handphone.

2. Sistem DTMF digunakan untuk mengkonversi penekanan angka dari pasangan frekuensi rendah dan frekuensi tinggi menjadi kode biner, sinyal Dual Tone Multiple Frequency yang dikirimkan oleh handphone dapat diterjemahkan menjadi data biner oleh IC CM8870. Dimana angka ganjil digunakan untuk menyalakan lampu. Sedangkan untuk mematikan lampu, handphone pengirim cukup menekan angka genap.

3. Alat ini dapat bekerja apabila handphone pengirim dapat melakukan panggilan ke handphone penerima. Handphone penerima akan menerima secara otomatis sehingga beban/lampu dapat dikendalikan dengan jarak yang sangat jauh, tergantung dari sinyal provider yang digunakan apakah masih terjangkau atau sebaliknya.

4. Alat beban listrik ini memiliki beberapa kelebihan ditinjau dari segi keamanannya. Sim card yang berada di dalam handphone penerima dapat diganti kapan saja, sehingga menambah tingkat kerahasiaan nomor pemanggilan pada handphone penerima, sinyal tone yang dihasilkan 
ponsel penerima di inputkan ke dalam IC CM8870 dan terbaca jelas oleh rangkaian DTMF decoder dan sistem DTMF ini sudah dirancang untuk membaca dan menghasilkan suatu nada tone yang sangat spesifik dari dua buah nada dengan frekuensi tertentu. Sehingga tidak akan terpengaruh noise dan interferensi nada yang lain.

\section{UCAPAN TERIMAKASIH}

Saya ucapkan kepada:

[1]. Putri IImi Nabila, S.T terimakasih atas bantuannya selama penelitian ini berlangsung.

\section{DAFTAR PUSTAKA}

[1] Tarigan, Pernantin. 2012. Dasar Teknik Digital. Graha IImu: Yogyakarta

[2] Bishop, Owen. 1987. Proyek Elektronika: Keamanan Rumah. PT Gramedia: Jakarta

[3] Tokheim, Roger L. 1986. Electronics and Microcomputer Circuits: 146 Practical Projects. Byte Books: U.S of America

[4] Pratomo, Andi. 2004. Rangkaian Elektronik Praktis: Kendaraan - Rumah. Puspa Swara: Jakarta

[5] Wasito S. 1997. Data Sheet Book 1: Data IC Linier, TTL Dan CMOS (Data Penting Komponen Elektronika. PT Gramedia Pustaka Utama: Jakarta

[6] Langley, Graham. 1986. Prinsip Dasar Telekomunikasi. PT. Multi Media Gramedia Grup: Jakarta

[7] 150 Rangkaian. 1985. Yayasan Pembina Pendidikan dan Hobi Elektronika "Binatronika"

[8] Data Praktis Elektronika - Kumpulan Data Elektronika Populer.1992. PT. Elex Media Komputindo: Jakarta

[9] MT8870D/MT8870D-1 ISO ${ }^{2}$-CMOS Integrated DTMF Receiver. 2005. Zarlink Semiconductor

[10] CD4013BM/CD4013BC Dual D Flip-Flop. 1988. National Semiconductor

[11] CD4043BC - CD4044BC Quad 3-STATE NOR R/S Latches - Quad 3-STATE NAND $R / S$ Latches. 1987.

[12] Fairchild Semiconductor CD4049UB, CD4050B. 1998. Texas Instruments

[13] 54154/DM54154/DM74154 4-Line to 16Line Decoders/Demultiplexers. 1989. National Semiconductor

[14] DECODERS/DRIVERS. 1988. Texas Instruments :
[15] ULN2003A, ULQ2003A - High Voltage, High Current - Darlington Transistor Arrays. 2007. Semiconductor Components Industries 